\title{
W poszukiwaniu męczeństwa. Analiza prawosławnych tekstów liturgicznych
}

\author{
ks. Marek Lawreszuk \\ Katedra Teologii Prawosławnej, Uniwersytet w Białymstoku \\ Polska \\ xmlawreszuk@gmail.com
}

Rev. Marek Ławreszuk, In search for martyrdom. Analysis of the Orthodox liturgical texts, Elpis, 17 2015: 31-36.

\begin{abstract}
In the hagiographic literature, descriptions of the martyrdom appeared an uncompromising stance a man who did not hesitate to confess and defend their faith, knowing that this may lead to martyrdom. The lives of the saints and liturgical texts often contain the term "desire to die" or "desire for martyrdom". How should we understand these words? Are they an expression of contempt for earthly life and the expectation of eternity with God? Are the roots of this idea dates back to the Gospel, or rather born with a Gnostic inspiration, and contempt for what earthly and material? The answers to these questions we will seek above all in the liturgical texts.
\end{abstract}

\begin{abstract}
Streszczenie: W literaturze hagiograficznej opisy śmierci męczeńskiej uwypuklały bezkompromisową postawę człowieka, który nie wahał się wyznawać i bronić swojej wiary, wiedząc, że może to prowadzić do męczeństwa. W żywotach świętych i tekstach liturgicznych często pojawiało się określenie: „pragnienie śmierci”, bądź „pragnienie męczeństwa”. W jaki sposób należy rozumieć te słowa? Czy są one wyrazem pogardy dla doczesności i oczekiwaniem wieczności z Bogiem? Czy korzenie tej idei sięgają Ewangelii, czy raczej rodzą się z gnostyckiej inspiracji i pogardy dla tego, co ziemskie i materialne? Odpowiedzi na te pytania będziemy poszukiwać przed wszystkim w tekstach liturgicznych.
\end{abstract}

Keywords: Martyrdom, Orthodoxy, faith, spirituality, liturgical texts, death

Słowa kluczowe: męczeństwo, Prawosławie, wiara, duchowość, teksty liturgiczne, śmierć

\section{Wstęp}

Męczeństwo za wiarę w Chrystusa stanowi fundament, na którym zbudowana została wspólnota pierwszych Chrześcijan. Bezgraniczna wiara i ufność w Dobrą Nowinę rodziła owoce $\mathrm{w}$ postaci bezkompromisowej postawy wiernych, którzy na krok nie chcieli zstąpić z drogi do Chrystusa, nawet jeśli, droga ta prowadziła przez tortury i śmierć.

W literaturze hagiograficznej często opisy męczeńskiej śmierci uwypuklały taką bezkompromisową postawę człowieka, który nie wahał się wyznawać i bronić swojej wiary, nawet jeśli wiedział, do czego taka postawa prowadzi. W żywotach świętych pojawiały się więc nie tylko opisy męczeńskiej śmierci, lecz również wprowadzenie, które ukazywało stosunek człowieka do tego, czym zakończy się jego bezwarunkowa wierność dla Chrystusa. W aktach męczeńskich i żywotach często pojawiało się określenie: „pragnienia śmierci”, bądź „pragnienia męczeństwa”. W jaki sposób należy rozumieć te słowa? Czy są one wyrazem pogardy dla doczesności i oczekiwaniem wieczności z Bogiem? A może wyrażają pogardę dla życia doczesnego? Czy korzenie tej idei sięgają Ewangelii, czy raczej rodzą się z gnostyckiej inspiracji i pogardy dla tego, co ziemskie i materialne?

Odpowiedzi na te pytania będziemy poszukiwać przed wszystkim w tekstach liturgicznych (Минея общая, 2002).

\section{Charakterystyka męczennika w tekstach liturgicznych}

W świetle tekstów liturgicznych zauważamy, że postawa świętego, który nie wyrzeka się swojej wiary i w konsekwencji przyjmuje śmierć męczeńską, nigdy nie jest traktowane jako „oczekiwanie na męczeństwo”. Chociaż termin ten pojawia się w tekstach liturgicznych dostatecznie często, to słowa „oczekiwanie męczeństwa” (cs. жaжda мученичества), mają znacznie mniej oczywiste i bardziej głębokie. „Oczekiwanie męczeństwa” to nie prowokowanie oprawców i szukanie możliwości otwartego konfliktu, lecz naturalna reakcja na twarde stanie $\mathrm{w}$ wierze. Jeśli pojawiają się zewnętrzne siły, które pragną zniszczyć bądź sprzeniewierzyć wiarę człowieka, bezwarunkowe poświęcenie staje się wynikiem tej wiary, nie zaś celem samym w sobie. W ten sposób męczeńska śmierć, jest przez Cerkiew rozumiana jako efekt niezachwianej wiary. Teksty liturgiczne mówią o niej bardzo przejrzyście nazywając ją „potrzebną śmiercią" (cs. нӰжнам сме́рть - Служба мученику, 1 katyzma poetycka po 1 katyzmie jutrzni, tłum. MŁ)(Минея общая, 2002, s. 81A). Chociaż określenie „potrzebna” może sugerować wskazanie na jej niezbędność, nie należy tego stwierdzenia w ten sposób wyjaśniać. Nie chodzi tutaj o powszechność tej drogi, lecz o jej prawidłowość w ściśle określonej sytuacji. W sytuacji poprzedzającej męczeństwo. 
Jest to wyzwanie, które spada na człowieka i każe wybierać spośród jednej z dwóch dróg: z Bogiem, lub bez Boga. Przy takim bezkompromisowym wyborze, pozostanie na drodze wiary, prowadzi właśnie poprzez męczeństwo do „potrzebnej śmierci" stanowiącej naturalną kontynuację dokonanego wyboru drogi. W tekstach liturgicznych słyszymy także o tym, że ten pierwotny wybór drogi z Bogiem był odpowiedni. Cerkiew wychwala męczennika mówiąc, iż dokonał on słusznego wyboru, nazywając go „odpowiednim": „Wykonałeś prawdziwy (odpowiedni) ruch” (cs. Tєчє́нïє гокєршн́вz Н̈́ттннне - Служба мученику, 1 katyzma роetycka po 2 katyzmie jutrzni)(Минея общая, 2002, s. 81A). Wybór drogi, którego skutkiem jest męczeńska śmierć jest także określany jako czyn, który stanowi miłą Bogu ofiarę:

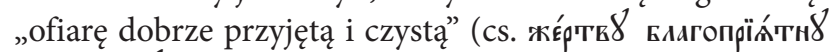
нิ прєчн́ст - 1 stichera wieczorna w dzień pamięci św. Teodora Stratelatesa, ton 2)(Минея август, 1996).

Mądry i właściwy wybór drogi jest poetycko przyrównany do wyboru źródła z czystą wodą, który nie dopuszcza do jej zanieczyszczenia: „Będąc, o święty, w posiadaniu w duszy swojej wody żywej, mętne i złe źródła osuszyłeś"

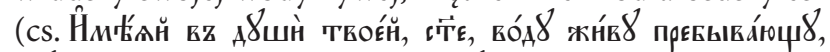

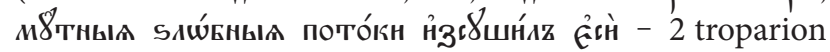
1 pieśni kanonu jutrzni męczennika)(Минея общая, 2002, s. 81B).

\section{Pragnienie męczeństwa nie jest dążeniem do samobójstwa}

Ocalić duszę - oto jest cel życia chrześcijanina. Często oczekiwanie męczeństwa może być pobieżnie przyrównane do braku troski o własne życie. Wybór, którego dokonuje męczennik, jest w laickiej analizie stawiany na równi z brakiem szacunku do życia a nawet charakteryzowane jako samobójstwo.

Myśl pozbawiona chrześcijańskiego fundamentu nie jest w stanie zrozumieć celu, który przyświecą męczennikom. Słysząc o czynach, które w konsekwencji prowadzą do tortur i cielesnej śmierci, nie mogą uniknąć porównania do samobójstwa, bądź działań prowadzących do samobójczej śmierci. Tak mogłoby się stać w przypadku słów z katyzmy jutrzni poświęconej męczennikom: „do śmierci

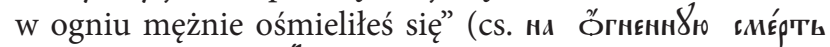

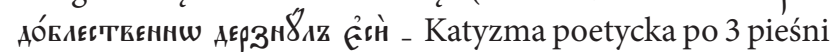
kanonu jutrzni męczennika)(Минея общая, 2002, s. 82B), czy w słowach stichery ku czci św. męcz. Izaaka z Optino:

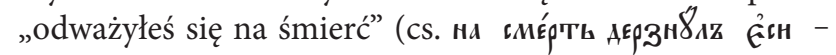
1 katyzma jutrzni 8 stycznia, św. męczennika mnicha Izaaka z Optino)(„Служба преподобномученнику Исаакию Старцу Оптинскому”, 2015), czy też w słowach: „kiedy na odważyłeś się na dobrowolną śmierć za Chrystusa" (cs. єгAA

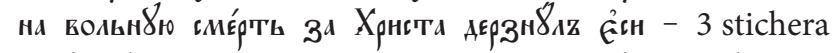
pochwalna jutrzni 8 stycznia, św. męczennika mnicha Izaaka z Optino)(„Служба преподобномученнику Исаакию Старцу Оптинскому”, 2015). Jednak hymnografia prawosławna wyraźnie podkreśla, że owocem męczeństwa nie jest śmierć i unicestwienie człowieka lecz życie. W stiche- rze św. wielkomęczennika Jerzego czytamy: „żywot wiecz-

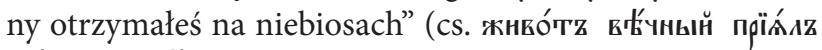

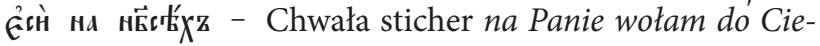
bie małej wieczerni 24 kwietnia, św. wielkomęczennika Jerzego)(Минея апрель, 1996, s. 195). Słów o akceptacji korony męczennika, nie należy więc utożsamiać $\mathrm{z}$ chęcią zakończenia życia. Wręcz przeciwnie, ze słów tych przebija wola wiecznego życia, przypodobania się Bogu i wypełnienia Jego woli: „ochoczo odważyłeś się na cierpienia, jak lew sławny, pogardzając ciałem jako mającym ulec zniszczeniu, o niezniszczalną zaś duszę mądrze zadbałeś i zostałeś rozpalony rozlicznymi rodzajami cierpień, Jerzy, jak złoto siedmiokroć oczyszczone" (cS. самохо́тн'Б АЕ

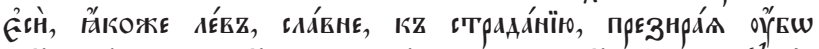

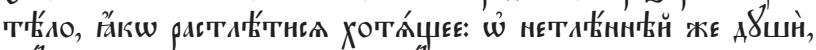

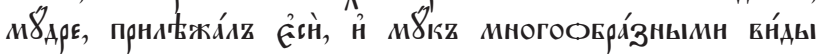

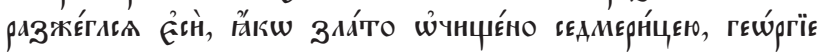
- 2 stichera na Panie wołam do Ciebie wielkiej wieczerni 24 kwietnia, św. wielkomęczennika Jerzego)(Минея апрель, 1996, s. 197). Męczeńska śmierć to nie zniszczenie, lecz wejście w triumf życia wiecznego, dlatego określana jest jako bezcenny dar: „owoc większy od złota, według słowa

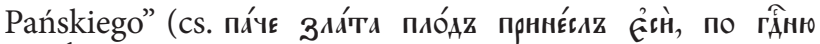
raár 8 - 6 stichera na Panie wołam do Ciebie wieczerni 27 lipca, św. wielkomęczennika Pantelejmona)(Минея июлий, 1996, s. 482).

Cielesna śmierć analizowana przez pryzmat nauki chrześcijańskiej, z trudem może być przyrównana do świeckich koncepcji, szczególnie tych, które stawiają to wydarzenie jako finał ludzkiej egzystencji. Z tego powodu naturalnie może się zrodzić konfuzja we współczesnym rozumieniu aktu dobrowolnej ofiary. Cerkiew zna dwie sytuacje, całkowicie odmienne, które jednak współcześnie mogą być ze sobą mieszane: męczeńska śmierć oraz samobójstwo. Samobójstwo, zgodnie z nauczaniem Cerkwi, to samowolne targnięcie na własne życie, dokonane w stanie załamania, pychy, utraty sensu życia. To, co łączy te diametralnie różne stany ludzkiej świadomości, to brak wiary i brak nadziei na Bożą pomoc. Samobójstwo staje się aktem własnej woli, a bardziej samowoli, która sprzeciwia się woli Bożej.

Męczeństwo nie ma niczego wspólnego z samobójstwem. Wręcz przeciwnie, jest przejawem wielkiej miłości do Boga i ludzi, jest świadectwem ufności i nadziei człowieka, którą kieruje ku Bogu. Zgodnie ze słowami Jezusa Chrystusa: „To jest moje przykazanie, abyście się wzajemnie miłowali, tak jak Ja was umiłowałem. Nikt nie ma większej miłości od tej, gdy ktoś życie swoje oddaje za przyjaciół swoich" (J 15,12-13). Święci męczennicy ofiarowali swe życie, zachowując wielką miłość i posłuszeństwo wobec Boga: „Licznymi mękami doświadczona została teraz Twoja ognista miłość do Upragnionego" (cs. М8̈камн

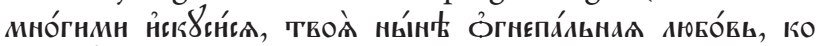

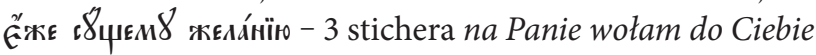
wieczerni 27 lipca, św. wielkomęczennika Pantelejmona) (Минея июлий, 1996, s. 481). Męczeństwo to akt dobrowolnej śmierci ciała, dla wiecznego życia duszy: „Za Zbawcę ucierpiałeś i śmiercią śmierć dobrowolną sławnie naśla- 


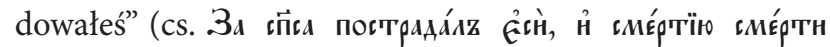

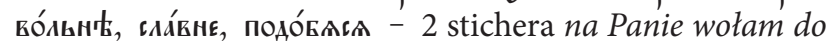
Ciebie wielkiej wieczerni 24 kwietnia, św. wielkomęczennika Jerzego)(Минея апрель, 1996, s. 197). Męczeństwo nie ma niczego wspólnego $\mathrm{z}$ samobójstwem, albowiem męczennicy wybrali życie wieczne, podczas, gdy akt samobójczy ma doprowadzić do „końca”, do śmierci, bez nadziei na dalsze życie. Samobójstwo jest aktem destrukcyjnym, celem samym w sobie, który ma ukrócić cierpienia bądź rozwiązać problemy, męczeństwo - drogą prowadzącą do ponadczasowego celu. Męczeńska śmierć jest więc realizacją drogi, którą wskazuje Bóg, jest środkiem prowadzącym do celu, nie zaś celem samym w sobie. Chrześcijańska wiara mówi o wiecznym życiu. W przeciwieństwie od samobójczej śmierci, która podważa wieczność życia, ucieka od niej i pragnie zniszczyć życie, męczeństwo domaga się wręcz życia, ale nie tego, które jest tutaj, na ziemi, a wiecznego, w Królestwie Niebiańskim. Dlatego cierpienie za wiarę w tekstach liturgicznych zostało określone jako „oczekiwanie nagrody i nieprzemijającego wysławiania Boga” (Минея oбщaя, 2002, s. 80A). Męczeńska śmierć nie jest określana jako zniszczenie ciała. Św. Klemens Rzymski, mówiąc o Kościele jako mistycznym Ciele Chrystusowym słusznie zauważa, iż destrukcja ciała następuje poprzez grzech, zaś męczeństwo ratuje ciało przed rozdarciem i rozdzieleniem (Starowieyski, 1998b, s. 72). Męczeńska śmierć niszczy materialne ciało, lecz ratuje duszę, która jednoczy się w jednym Ciele Chrystusowym. W dniu pamięci świętych serbskich nowomęczenników Paisjusza i Awakuma słyszymy: „nie chcieliście wyrzec się Chrystusa, Dawcy Życia dla, lecz konieczną śmiercią ginąc, podążyliście na niebiosa" (cs. HE

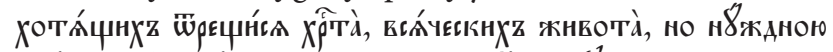

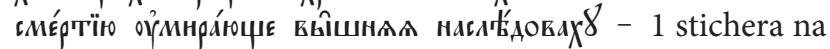
Panie wołam do Ciebie wieczerni św. Paisjusza i Awakuma, 17 grudnia) (Минея, декабрь, 1997, s. 485). W tekstach liturgicznych i dziełach Ojców Kościoła zauważamy wyraźne zaakcentowanie radości, z którą męczennicy podążają na śmierć. „Radując się przyjąłeś chwalebną śmierć” (cs.

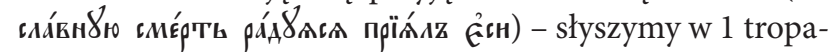
rionie 3 pieśni kanonu jutrzni ku czci św. Jana Chrzciciela (Минея, декабрь, 1997, s. 545).

Jedno z najstarszych świadectw męczeńskiej śmierci za wiarę Chrystusa, związane jest ze św. Ignacym Antiocheńskim. Biskup Antiocheński, o którym Euzebiusz z Cezarei pisał, iż był on drugim następcą Piotra na tronie antiocheńskim, został $\mathrm{w}$ czasie prześladowań uwięziony i wysłany z Syrii do Rzymu, by tam, o ile nie wyrzeknie się Chrystusa, zostać zamęczonym. W czasie drogi do Rzymu, którą św. Ignacy odbywał w eskorcie 10 żołnierzy, daje on jedno z najbardziej wartościowych świadectw dotyczących znaczenia męczeństwa. Świadectwo to zachowało się w „Liście do Rzymian”, których św. Ignacy przestrzega, aby przypadkiem nie starano się uwolnić go od męczeństwa.

Św. Ignacy wybór drogi, którą podąża określa w bardzo prosty sposób: „Nie chcę, abyście starali się podobać ludziom, lecz abyście podobali się Bogu tak, jak rzeczywiście Mu się podobacie" (św. Ignacy Antiocheński, 1988, s. 128). Bycie z Bogiem, to droga świadectwa, tj. męczeństwa. $Z$ tej drogi św. Ignacy nie chce schodzić, albowiem prowadzi ona prosto do Boga. Co więcej, przestrzega adresatów swojego listu, z którymi spotka się w Rzymie, aby nie czynili starań o jego uwolnienie. „Nie próbujcie mi dać nic więcej ponad to, aby krew moją wylano na ofiarę Bogu" (św. Ignacy Antiocheński, 1988, s. 128). Oczywiście męczeństwo jest aktem wielkiej odwagi. Św. Ignacy jest świadom lęku, który może go ogarnąć. $Z$ tego powodu prosi on współwyznawców o modlitwę, która napełni go „siłą wewnętrzną i zewnętrzną, abym nie tylko mówil, lecz również chciał, abym nie tylko nazywał się chrześcijaninem, lecz nim się również okazał" (św. Ignacy Antiocheński, 1988, s. 129).

W ujęciu św. Ignacego męczeństwo jest aktem dobrowolnej śmierci, lecz śmierci cielesnej, która prowadzi do życia. W przeciwieństwie do świeckich koncepcji samobójstwa, św. Ignacy traktuje męczeństwo jako drogę ku celu, a nie cel. Drogę męczennika przyrównuje do losu pszenicy: „Pszenicą jestem Bożą, a zmielony zwierzęcymi zębami, okażę się czystym chlebem Chrystusa. [...] Błagajcie za mnie Chrystusa, abym z pomocą zwierząt stał się ofiarą dla Boga. [...] Kiedy [...] będę cierpiał, wtedy stanę się wyzwoleńcem Jezusa Chrystusa i powstanę w Nim wolny" (św. Ignacy Antiocheński, 1988, s. 129). Słowa te nawiązują do nauki apostoła Pawła skierowanej do mieszkańców Koryntu: „Albowiem ten, kto został powołany w Panu jako niewolnik, jest wyzwoleńcem Pana. Podobnie i ten, kto został powołany jako wolny, staje się niewolnikiem Chrystusa" (1Kor 7,22).

Śmierć ma prowadzić do Królestwa, w którym życie będzie wieczne. Oczekiwanie na to życie, do którego święty dąży przez cierpienie i męczeństwo, przezwycięża ludzki strach i niweluje obawy, tak, iż św. Ignacy wzywa: „Niechaj żaden $\mathrm{z}$ bytów widzialnych ani niewidzialnych nie próbuje mi przez zawiść przeszkadzać w dojściu do Chrystusa" (św. Ignacy Antiocheński, 1988, s. 130).

Męczeńska śmierć nie jest więc odrzuceniem życia jako takiego, lecz wyborem życia wiecznego. Jest potwierdzeniem wiary w nieśmiertelność. Jest triumfem chrześcijańskiej nadziei i ufności. Św. Cyryl Jerozolimski przyrównuje śmierć do ostatecznego testu, który objawia głębię naszej wiary. Przed śmiercią niczego nie możemy być pewni - także naszej niezłomności w drodze do Boga. Św. Cyryl ukazuje to na przykładzie igrzysk: „Każdy zawodnik otrzymuje wieniec lub zostaje zawstydzony dopiero po zakończeniu walki. Nigdy nie wieńczy sędzia w czasie walki, lecz czeka, aż wszyscy zawodnicy dojdą do celu, i dopiero wtedy rozstrzyga i rozdziela nagrody i wieńce. Tak i Bóg postępuje. Jak długo toczy się w tym życiu walka, sprawiedliwym udziela pomocy, lecz dopiero później daje pełną nagrodę" (św. Cyryl Jerozolimski, 2000, s. 301).

\section{Cierpienie za wiarę}

Męczeństwo to owoc konfliktu Stwórcy z diabłem. Niezachwiane trwanie $\mathrm{w}$ wierze sprawia, że męczennik „skruszy głowę żmii, i krwią uświęci ziemię" (cs. smí́k 8 гаAк 
ły sticher stroficznych wieczerni męczennika) (Минея общая, 2002, s. 80B). Troparion męczenników wyraźnie wskazuje, że w efekcie męczeńskiej śmierci zniszczony zostaje nie męczennik, lecz ci, którzy stali się jej sprawcami: „Męczennik Twój, Panie, ... pokonał ciemiężycieli, skruszył także pozbawione mocy zuchwalstwo demonów"

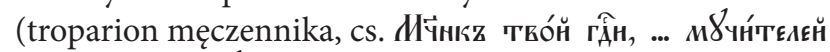

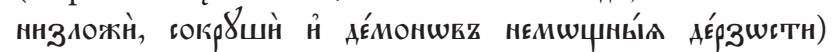
(Минея общая, 2002, s. 80B). Powszechne jest określenie męczenników jako zwycięzców, którzy swoją śmiercią zniszczyli swoich oprawców: „Niezwyciężonego żołnierza Chrystusowego, pełnego męstwa zwycięzcę nad wrogami"

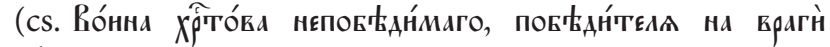
до́влАго - katyzma poetycka jutrzni męczennika) (Минея общая, 2002, s. 81A). Postawa męczennika jest postawą niezachwianej decyzji: „Byłeś niezachwiany i niewzruszo-

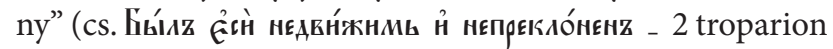
4 pieśni kanonu jutrzni męczennika) (Минея общая, 2002, s. $82 \mathrm{~B})$.

Cerkiew wychwala męczenników jako tych, którzy swoją niezłomnością dali dowód niezachwianej wiary i tym zwyciężyli zło. Ufność, z którą męczennicy kroczyli na śmierć, stanowi wzorzec znany już z I wieku. O tej nadziei i zawierzeniu własnego życia woli Bożej wspominał już św. Klemens Rzymski, który w obliczu prześladowań przypominał: „Najwyższy jest obrońcą i tarczą dla wszystkich, którzy w czystości sumienia służą Jego świętemu imieniu. Jemu to chwała na wieki wieków” (św. Klemens Rzymski, 1988, s. 71).

Męczeńska śmierć przypomina o zbawiennej ofierze Chrystusa. Zwycięstwo nad śmiercią i prześladowcami kryje się właśnie $\mathrm{w}$ fundamencie naszej wiary - $\mathrm{w}$ dogmacie o zbawieniu przez Krzyż. Chrystus przezwyciężył śmierć i wyzwolił ludzkość spod władzy szatana. Śmierć stała się dla chrześcijanina nie końcem, a chwilą która prowadzi dalej, do życia wiecznego. Dlatego śmierć cielesną, a przede wszystkim śmierć męczeńską, Kościół nazwał „narodzinami”. To określenie zauważamy już w liście św. Ignacego Antiocheńskiego: „Tego szukam, który za nas umarł, Tego pragnę, który dla nas zmartwychwstał. Moje narodziny się zbliżają" (św. Ignacy Antiocheński, 1988, s. 130). Narodziny są zwycięstwem nad śmiercią, ale są również triumfem miłości, albowiem męczeństwo, jak to wcześniej ukazaliśmy, nie jest celem samym w sobie. Przypomina nam o tym Pieśń nad Pieśniami: „Bo jak śmierć potężna jest miłość” (PnP 8,6). Krzyż Zbawiciela to triumf miłości do człowieka. Męczeństwo staje się triumfem miłości człowieka do Boga (Ware, 1999, s. 86). Dlatego męczennika hymnografia określa jako tego, który stał się: „Upiększony miłością

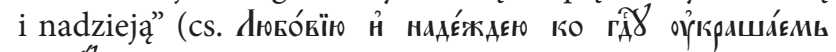

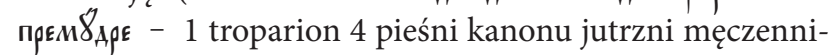
ka)(Минея общая, 2002, s. 82B).

Narodziny do nowego życia to zwycięstwo nad śmiercią. Zwycięstwo tego człowiek nie zawdzięcza jednak samemu sobie, lecz Zbawicielowi. Granica śmierci cielesnej jest jednak trudną do przebycia, co widzimy, w słowach Pisma Świętego, w arcykapłańskiej modlitwie Jezusa Chrystusa, czy w listach ap. Pawła (por. m.in. Flp 1,20b-23). Mę- czeństwo staje się więc nie tylko wejściem w życie wieczne, a więc zwycięstwem nad śmiercią, staje się również triumfem nad ludzkimi słabościami.

\section{Męczeństwo jako zwycięstwo nad ludzkimi słabościami}

Cerkiew nie idealizuje męczenników i nie stara się ich odrealnić. Ukazuje ludzi, których ofiara oznaczała walkę z własnymi słabościami, z ludzkim lękiem, ze strachem przed bólem i śmiercią. Męczennik nie jest w tekstach liturgicznych przedstawiany jako odrealniony heros, lecz jako zwyczajny człowiek, który wspierany łaską Bożą znosi cierpienia i tortury, których nie chce, lecz które objawiły się na jego drodze. W czasie jutrzni ku czci męczennika, czytamy: „Męczenniku! Byłeś w stanie, pozostając w słabości cielesnej pokonać przepełnioną chytrością żmiję" (cs. Коз мórлz

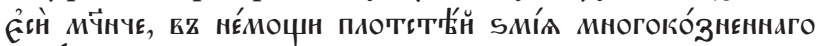
погУви́тн - 3 troparion 5 pieśni kanonu jutrzni męczennika) (Минея общая, 2002, s. 82B). Ikos nabożeństwa ku czci męczennika wzywa zaś do wychwalenia jego jako zwycięzcy, który „nieustannie pozostając w cierpieniu, był wielkim poprzez prawdziwe wyznawanie Boga, i został objawiony

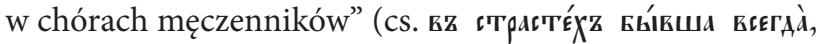

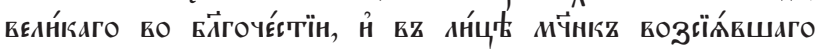
- ikos jutrzni męczennika) (Минея общая, 2002, s. 83A).

O zwycięstwie nad słabością i strachem mówi również św. Ignacy Antiocheński. „Książe tego świata chce mnie porwać i zburzyć moje nastawienie wobec Boga" (św. Ignacy Antiocheński, 1988, s. 130). Święty walczy z tą pokusą, stara się pokonać ją jako słabość ludzkiej natury i w wyniku tej wewnętrznej walki jest w stanie powiedzieć: „Nie chcę już żyć na sposób ludzki” (św. Ignacy Antiocheński, 1988, s. 130). Słowa te korespondują ze sticherami jutrzni ku czci męczennika, w których słyszymy m.in.: „ani zwierzęta, ani koła, ani żadna inna męka, nie są w stanie kiedykolwiek oddzielić mnie od miłości mojego Chrystusa" (cs. нн sв Ǩ̈̈̈̈в,

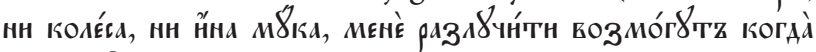

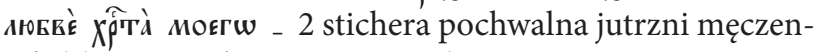
nika)(Минея общая, 2002, s. 84).

Zwycięstwo nad słabościami to misja chrześcijanina. To również droga do prawdziwej wolności. Dlatego męczeństwo jest określane jako wyzwolenie i wkroczenie w prawdziwą wolność (Evdokimov, 2001, s. 133). Teksty liturgiczne przyrównują męczeństwo do słów Chrystusa „Jeśli kto chce pójść za Mną, niech się zaprze samego siebie, niech weźmie krzyż swój i niech Mnie naśladuje. Bo kto chce zachować swoje życie, straci je; a kto straci swe życie z mego powodu, znajdzie je" (Mt 16,24-25). Dlatego w wielu tekstach liturgicznych ku czci męczenników słyszymy: „krzyż bowiem Chrystusowy na ramię wziąłeś” (cs. кк्ิ Tтz

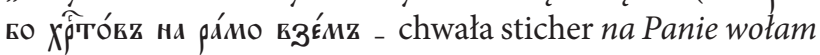
do Ciebie wielkiej wieczerni 24 kwietnia, wielkomęczennika Jerzego) (Минея апрель, 1996, s. 198). Męczeństwo staje się indywidualnym krzyżem, ale jest przyrównywany również do kielicha Wieczerzy Mistycznej: „zbawienny kielich

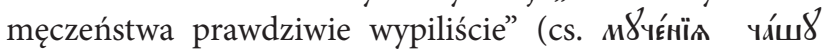




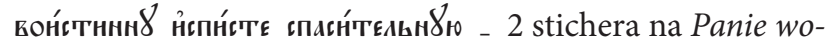
tam do Ciebie wieczerni 5 kwietnia, męcz. Teodula i Agafopada)(Минея апрель, 1996, s. 52).

Pokonanie słabości ciała, strachu przed bólem i cierpieniem to deklaracja niezachwianej wiary w słowa Chrystusa i niezłomne podążanie za Nim. Męczeństwo staje się ofiarą, która składana Bogu świadczy o wierze świętego. O tym również mówią teksty liturgiczne, chociażby stichery ku czci św. wielkomęczennika Jerzego: „stałeś się ofiarą

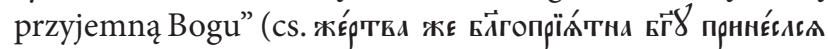
E̊ $\mathbf{c H}$ - i teraz sticher na stichownie wieczerni 24 kwietnia, wielkomęczennika Jerzego) (Минея апрель, 1996, s. 52).

\section{Droga do męczeństwa jest drogą pokoju}

W tekstach liturgicznych ku czci męczenników czytamy: „Ścieżką twojej wędrówki, o godny wyjątkowego zachwytu, skierowałeś się na drogę pokoju, wstępując do Kró-

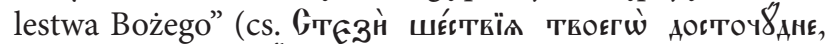

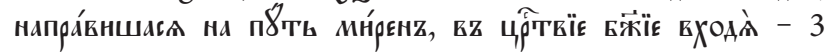
troparion 3 pieśni kanonu jutrzni męczennika) (Минея общзая, 2002, s. 82A). Słowa te korespondują ze znaną od początków chrześcijaństwa ideą „być godnym powołania”, o której mówił św. Klemens Rzymski. Świadomość daru, który człowiekowi daje Bóg zobowiązuje do kroczenia drogą, która uświęca (Starowieyski, 1998b, s. 64). Wielkość i chwała, idąc dalej tokiem rozważań św. Klemensa, nie są owocem ludzkich uczynków, czynionych jedynie z własnej, ludzkiej woli, lecz owocem woli Bożej (Starowieyski, 1998b, s. 65). Męczeństwo jest więc podążaniem drogą, na którą przywołuje Bóg - drogą chrześcijańskiego powołania. Świadectwo prawdy prowadzi do konfrontacji ze światem, ale świat nie jest w stanie zniszczyć ducha. Obawiając się przede wszystkim zbawienia dusz, ludzie nie wahali się poświęcić swoje zdrowie, życie cielesne, swoje emocje i uczucia i złożyć je jako świadectwo prawdy (Starowieyski, 1998b, s. 65).

Droga pokoju, to droga, która wykracza poza ziemską sprawiedliwość. Jej owoce również wykraczają poza doczesność: „dostąpiłeś do niewidzialnych darów” (cs. прнше́́রz

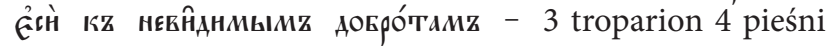
kanonu jutrzni męczennika)(Минея общая, 2002, s. 82A). Zbawiciel słusznie przestrzegał uczniów: „... oto was posyłam jak owce między wilki” (Łk 10,3), wskazując przy tym, aby nie bali się tych, którzy mogą zniszczyć ludzkie ciało. Chrystus nawoływał: „Nie bójcie się tych, którzy zabijają ciało, lecz duszy zabić nie mogą. Bójcie się raczej Tego, który duszę i ciało może zatracić w piekle" (Mt 10,28-29). Dlatego $\mathrm{w}$ jednej z najstarszej homilii chrześcijańskiej, przez niektórych przypisywanej św. Klemensowi Rzymskiemu, czytamy wezwanie: „...walczmy, abyśmy wszyscy wieniec zdobyli" (Starowieyski, 1998a, s. 95).

Walka ta nie jest jednak walką, która niszczy, lecz staje się aktem twórczym. Męczeństwo nie jest skierowane przeciw prześladowcom. Ich osądem zajmie się Bóg. Męczennik walczy ze swoją słabością, ze swoim lękiem. To jest ideał chrześcijańskiej pokory, której szczytową formą jest pokora kochająca, o której słyszymy w słowach Fiodora Dostojewskiego: „Kochająca pokora jest straszną siłą - silniejszą od wszystkiego; nie ma nic jej równego" (Ware, 1999, s. 87). Męczeństwo to akt twórczy, który przemienia człowieka cielesnego w człowieka duchowego, w osobę godną Królestwa niebiańskiego. $Z$ tego powodu często w tekstach liturgicznych męczenników określa się jako tych, którzy zdobyli laur, wieniec lub koronę. Nie są to nagrody materialne, ziemskie i przemijające, lecz wieczne, albowiem dotyczą życia w Królestwie Bożym: „znalazłeś pobożności zapłatę, męczenniku, okazując się ukoronowanym i niezwyciężonym rycerzem Chrystusa Boga naszego" (cs. зва́нїємz

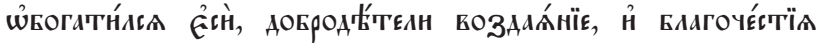

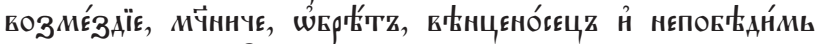

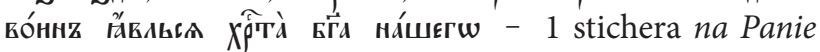
wołam do Ciebie wieczerni 27 lipca, św. wielkomęczennika Pantelejmona)(Минея июлий, 1996, s. 481).

Pragnienie męczeństwa, to dążenie do Boga, to poczucie eschatologicznej bliskości ze Stwórcą i Zbawicielem, które wybrzmiewa w słowach „Przyjdź, Panie Jezu!” (Ap 22,20 ). W pragnieniu tym nie ma destrukcji, a brzmi chęć zbliżenia się ku Bogu. Nie ma w tym wezwaniu romantycznej idei poświęcenia się dla ogółu, swoistego walenrodyzmu, albowiem chęć ta zbudowana jest na fundamencie pozytywnym - bycia z Bogiem, osiągnięcia zbawienia, trwania w świadectwie Prawdy. Wszystkie powyższe idee odnajdziemy $\mathrm{w}$ prawosławnej hymnografii, $\mathrm{w}$ poetyckich tekstach liturgicznych, w pieśniach i sticherach.

\section{Zakończenie}

Męczennicy stanowią wzór godnej postawy uczniów Chrystusa, tych, którzy z świadomi Bożej miłości, $\mathrm{z}$ wdzięcznością wstępują na ukazaną przez Boga drogę. „Tym zaś, co cierpieli z ufnością, przypadną w dziedzictwie cześć i chwała" - pisał św. Klemens Rzymski (Starowieyski, 1998b, s. 72). Dlatego Cerkiew prawosławna stawia męczenników jako fundament wspólnotowej modlitwy, sprawując Boską Liturgię na świętych antyminsach zawierających cząsteczki relikwii świętych męczenników. Na krwi męczenników, i ich drodze życia, kolejne pokolenia wiernych zbliżają się do Boga i starają się kroczyć wyznaczoną przez Niego drogą.

Końcem drogi męczenników staje się ich wejście do Królestwa Niebiańskiego. Osiągnięcie celu, stanowi zakończenie igrzysk, o których pisał w 18 katechezie św. Cyryl Jerozolimski (św. Cyryl Jerozolimski, 2000, s. 301), staje się darem chleba, który powstał z pszenicy cielesnego życia, o którym wspominał św. Ignacy Antiocheński, ale przed wszystkim jest uczestnictwem w Chrystusie, w Jego triumfie nad zniszczeniem i śmiertelnością. Ze słów Pisma Świętego wiemy, że droga ma być dla chrześcijan drogą powszechną. Apostoł Paweł wzywa do konieczności następującego postępowania: „Trzeba, - mówi apostoł Paweł, wskazując właśnie na powszechny charakter słów, dotyczących każdego wiernego - ażeby to, co zniszczalne, przyodzia- 
ło się w to, co niezniszczalne, a to, co śmiertelne, aby się odziało w nieśmiertelność" (1 Tes 4,16)(BT, 2003).

Pismo Święte pieczętuje te rozważania zdaniem „Umarli w Chrystusie powstaną pierwsi” (1 Kor 15,53), co koresponduje ze słowami 1 troparionu 8 pieśni kanonu jutrzni męczennika (Минея общая, 2002, s. 83A). Te słowa pozwalają traktować męczeńską śmierć jako chrześcijański wzorzec, który niezmiennie istnieje w Cerkwi Chrystuso- wej od czasów Chrystusa, poprzez Apostołów, Świętych Ojców, i poprzez niezliczone przykłady świętych męczenników, których liturgicznie wychwala Cerkiew prawosławna.

Na podstawie powyższej analizy, możemy stwierdzić iż hymnografia Cerkwi prawosławnej, potwierdza i powiela fundamenty prawosławnej antropologii i eschatologii, wskazując drogę męczeństwa, jako idealną drogę do życia wiecznego w Królestwie Bożym.

\section{Bibliografia}

Evdokimov, P. (2001). Szalona miłość Boga. (M. Kowalska, Tłum.). Białystok.

Pismo Święte Starego i Nowego Testamentu, Biblia Tysiaclecia. (2003) (IV.). Wydawnictwo Pallottinum.

Starowieyski, M. (Red.). (1998a). Najstarsza homilia chrześcijańska. W Pierwsi świadkowie. Pisma Ojców Apostolskich. Kraków: Wydawnictwo M.

Starowieyski, M. (Red.). (1998b). Pierwsi świadkowie. Pisma Ojców Apostolskich (II.). Kraków: Wydawnictwo M.

św. Cyryl Jerozolimski. (2000). Katechezy przedchrzcielne i mistagogiczne. (W. Kania, Tłum., M. Bogucki, Red.). Kraków: Wydawnictwo „M”.

św. Ignacy Antiocheński. (1988). List do Rzymian. W M. Starowieyski (Red.), Pierwsi świadkowie. Pisma Ojców Apostolskich. Kraków: Wydawnictwo M.

św. Klemens Rzymski. (1988). List do Kościoła w Koryncie. W M. Starowieyski (Red.), Pierwsi świadkowie. Pisma Ojców Apostolskich. Kraków: Wydawnictwo M.
Ware, K. (1999). Prawosławna droga. (Siostra Nikolaia, Tłum.). Białystok: Bractwo Młodzieży Prawosławnej w Polsce.

Минея август. (1996). Москва: Московский Сретенский монастырь, издательство „Правило веры”.

Минея апрель. (1996). Москва: Московский Сретенский монастырь, издательство „Правило веры”.

Минея июлий. (1996). Москва: Московский Сретенский монастырь, издательство „Правило веры”.

Минея общая. (2002). Москва: Издательский Совет Русской Православной Церкви.

Минея, декабрь. (1997). Москва: Московский Сретенский монастырь, издательство „Правило веры”.

Служба преподобномученнику Исаакию Старцу Оптинскому. (2015). Pobrano 30 czerwiec 2015, z http://newmartyros.ru/gimnografiya/gimnografiya-prmch-isaakiya-bobrakova-1938.html

Rozmiar artykułu: 0,8 arkusza wydawniczego 
ISSN 1508-7719

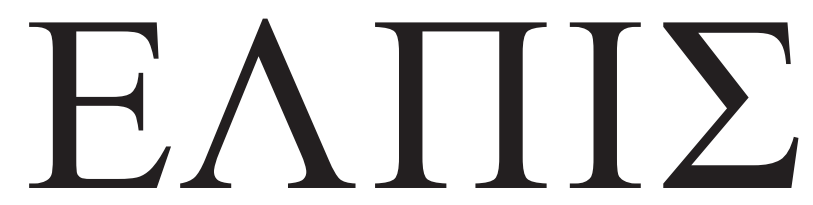

CZASOPISMO TEOLOGICZNE KATEDRY TEOLOGII PRAWOSŁAWNEJ UNIWERSYTETU W BIAŁYMSTOKU

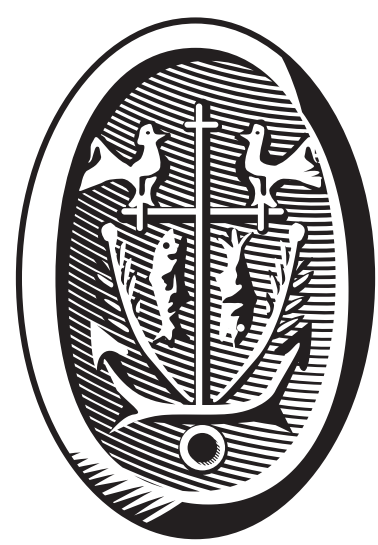

ADRES REDAKCJI

15-097 Białystok, ul. M. Skłodowskiej-Curie 14 tel. 85 745-77-80, e-mail: redakcja@elpis.edu.pl www.elpis.uwb.edu.pl 